Pre-print of: Cadena, E. et al. "A methodology to determine gaseous emissions in a composting plant" in Waste management (Elsevier), vol. 29 issue 11 (Nov. 2009) p. 2799-2807. The final versión is available at DOI 10.1016/j-wasman.2009.07.005

\title{
A METHODOLOGY TO DETERMINE GASEOUS EMISSIONS IN A COMPOSTING PLANT
}

\author{
Erasmo Cadena, Joan Colón, Antoni Sánchez*, Xavier Font, Adriana Artola
}

Composting Research Group. Department of Chemical Engineering.

Universitat Autònoma de Barcelona. 08193-Bellaterra (Barcelona, Spain)

* Corresponding author:

Antoni Sánchez

antoni.sanchez@uab.cat

Phone: +34935811019

Fax: +34 935812013 


\section{Abstract}

Environmental impacts associated to different waste treatments are of interest in the decisionmaking process at local, regional and international level. However, all the environmental burdens of an organic waste biological treatment are not always considered. Real data on gaseous emissions released from full-scale composting plants are difficult to obtain. These emissions are related to the composting technology and waste characteristics and therefore, an exhaustive sampling campaign is necessary to obtain representative and reliable data of a single plant. This work proposes a methodology to systematically determine gaseous emissions of a composting plant and presents the results obtained in the application of this methodology to a plant treating source separated organic fraction of municipal solid waste (OFMSW) for the determination of ammonia and total volatile organic compounds (VOC). Emission factors from the biological treatment process obtained for ammonia and VOC were $3.9 \mathrm{~kg} \mathrm{Mg} \mathrm{OFMSW}^{-1}$ and $0.206 \mathrm{~kg} \mathrm{Mg}$ $\mathrm{OFMSW}^{-1}$ respectively. Emissions associated to energy use and production were also quantified $\left(60.5 \mathrm{~kg} \mathrm{CO}_{2} \mathrm{Mg} \mathrm{OFMSW}^{-1}\right.$ and $\left.0.66 \mathrm{~kg} \mathrm{VOC} \mathrm{Mg} \mathrm{OFMSW}^{-1}\right)$. Other relevant parameters such as energy and water consumption and amount of rejected waste were also determined. A new functional unit is presented to relate emission factors to the biodegradation efficiency of the composting process and consists in the reduction of the Respiration Index of the treated material. Using this new functional unit, the atmospheric emissions released from a composting plant are directly related to the plant specific efficiency.

Keywords: Ammonia, composting, emission factors, organic waste, respiration index, VOC. 


\section{Introduction}

Solid waste management, and particularly its organic fraction, is becoming a global problem in developed countries. At present different technologies are being applied to reduce landfill destination of organic wastes, improving recycling of organic matter and nutrients (European Commission, 1999), as landfill is responsible for a considerable contribution to global warming (Mor et al., 2006). Among the emerging technologies to treat the organic fraction of municipal solid wastes, anaerobic digestion and composting are widely considered as environmentally friendly technologies. For instance, Spain presents an exponential growth of such technologies, although it is difficult to find reliable up-to-date data on plants in operation at national level. In 2005, 82 composting plants and 9 anaerobic digestion plants were operating in Spain treating an overall amount of $7824 \mathrm{Mg}$ of source-separated and mixed municipal solid waste (Ministerio de Medio Ambiente y Medio Rural y Marino, 2009).

Although the objective of a waste treatment plant is to safely transform wastes to less pollutant and/or hazardous substances or, when possible, useful products reducing their possible impact to the environment, there are some inherent environmental loads associated to organic wastes recycling in large-scale facilities. Odour emissions and atmospheric pollution are the most common, although energy and water consumption coupled with leachate generation also need to be considered in these facilities. Two main groups of studies on the environmental performance of organic waste treatment plants can be found in the literature: those exclusively focused on the atmospheric emissions of the biological treatment process itself and those related to the overall impact derived from these plants, which, in addition to atmospheric emissions, include energy consumption, wastewater generation and waste transportation to finally perform a Life Cycle Assessment (LCA) of the waste treatment scenario. Another emerging group of works is focused on the importance of gaseous releases towards the occupational and non-occupational exposure to 
these chemicals and its associated risks, as reported in recently published studies (Tolvanen et al., 2005; Domingo and Nadal, 2009).

Important conclusions can be obtained from atmospheric emissions studies. Composting plants present numerous odour and pollution sources, including reception and materials handling, forced aeration composting, stock piling, etc. Gaseous emissions in composting facilities are typically constituted by nitrogen-based compounds, sulphur-based compounds and a wide group of compounds denominated Volatile Organic Compounds (VOC) (Eitzer, 1995).

Among the nitrogen-based compounds released to the atmosphere, ammonia has received much attention because it can be easily identified from other composting odours, it often represents the main nitrogen gas emitted during composting and it can be released in large amounts. Reported ammonia emissions in a composting process of organic fraction of municipal solid wastes (OFMSW) vary between 18 and $1150 \mathrm{~g} \mathrm{NH}_{3} \mathrm{Mg}$ waste $^{-1}$ (Clemens and Cuhls, 2003) whereas peaks of ammonia concentration up to $700 \mathrm{mg} \mathrm{NH}_{3} \mathrm{~m}^{-3}$ have been detected in exhaust gases from wastewater sludge composting facilities (Haug, 1993). In studies performed at laboratory level with different wastes it was shown that ammonia emissions exhibit a clear correlation with process temperature, reaching maximum values during the thermophilic period (Pagans et al., 2006a). Aeration rate, $\mathrm{pH}$ and initial total ammonium nitrogen are other factors influencing directly ammonia emissions in a composting process (Beck-Friis et al., 2001; Cronje et al., 2002; Grunditz and Dalhammar, 2001).

Another main group of gaseous pollutants emitted from composting facilities are VOC. According to Eitzer (1995), who undertook an exhaustive characterization of the different VOC emitted at the different stages of the composting process, most VOC in composting plants are emitted at the early stages of process i.e. at the tipping floors, at the shredder and during the initial forced aeration composting period. Other authors related the presence of some VOC and its 
concentration to the odour nuisance level (Defoer et al., 2002; Mao et al., 2006). Incomplete or insufficient aeration during composting can produce sulphur compounds of intense odour, whereas incomplete aerobic degradation processes result in the emission of alcohols, ketones, esters and organic acids (Homas and Fischer, 1992). Van Durme et al. (1992) identified dimethyl sulphide, dimethyl disulphide, limonene and $\alpha$-pinene as the most significant odorous VOC at a wastewater sludge composting facility. According to this work, the latter two compounds were released from wood chips used as bulking agent. At laboratory scale, total VOC concentration in exhaust gases from composting processes of different wastes has been also studied and it was concluded that the highest concentrations of VOC were emitted during the first $48 \mathrm{~h}$ of process (Pagans et al., 2006b). These authors also stated that VOC emissions could not be correlated with the biological activity of the process, contrarily to the case of ammonia. In addition to odorous disturbance that VOC can cause, the presence of xenobiotic VOC in gaseous emissions from municipal solid waste composting has also been reported (Komilis et al., 2004).

Literature reports many studies on Life Cycle Assessment (LCA) of solid waste management and/or treatment processes (Lee et al., 2007; Blengini, 2008; Banar et al., 2009). However, a common trend in most works published is a lack of field full-scale data corresponding to real processes working under real conditions. In LCA analysis of waste management systems including a large number of processes, it is obvious that general assumptions must be made: gaseous emissions of the vehicles used for waste transportation, distances between collection points and waste treatment installations, waste composition, quantities and type of waste generated during treatments, etc. (Eriksson et al., 2005; Emery et al., 2007). However, special care should be taken in the use of bibliographic data on scenarios different to that for which the data were obtained. This practice can lead to a final environmental analysis with considerable errors in the results obtained, since the type of technology, the waste composition and the quality 
of process management will strongly influence the results (Fricke et al., 2005). In waste management, theoretical LCA studies with different waste treatment and handling operations use different data sources to overcome the difficulty of obtaining reliable data from studies carried out with the same waste in the same area (Güereca et al., 2006). In addition to these limitations, the use of data obtained at laboratory scale is not recommended as in most cases process conditions at laboratory scale do not correspond to those of a full-scale treatment plant (Szanto et al., 2007). Moreover, LCA studies focused on a particular organic solid waste treatment facility are scarce.

According to these considerations, data obtained by means of rigorous field studies in composting facilities are necessary to: (i) calculate emission factors that permit the comparison among different treatment plants, (ii) contribute to Regional and National databases on atmospheric emissions from industrial activities as, for instance, the European Pollutant Emission Register (EPER) (European Commission, 2000), (iii) obtain on-site indicators of the environmental performance of different waste treatment processes to improve the design and operation of these plants in terms of environmental impact, and (iv) develop a reliable LCA of each composting technology allowing the selection of the most adequate on an overall environmental impact basis.

Therefore, the main objective of this work is to develop a methodology to determine the overall emission of any chemical compound in full-scale composting facilities, since this is one of the environmental issues presenting a considerable lack of experimental data. As a case study, ammonia and total VOC are the selected pollutants studied in a composting facility treating source-separated OFMSW including in-vessel forced aeration composting and aerated-windrow curing. As a second objective, a new functional unit based on solid-state respirometry is also 
presented with the aim to include the plant performance related to the extent of organic matter biodegradation and stabilization in the values of emission factors for each analysed compound.

\section{Experimental methodology}

The methodology proposed to determine gaseous emissions associated to a composting plant is composed of four different steps: (i) data collection on plant characteristics and operation, (ii) determination of atmospheric emissions, (iii) laboratory analysis and (iv) calculation of emission factors. Following this method not only the gaseous emissions are determined but also their relationship with plant operation.

This methodology has been applied to a composting plant located in Catalonia (Spain) treating source separated OFMSW. A schematic representation of this plant and the overall mass balance in the most important operations of the composting process is presented in Figure 1. Specifically, the decomposition phase takes place during two weeks in closed composting reactors with controlled aeration, watering and gas collection and treatment by means of a wet scrubber and a biofilter, whereas the curing phase is carried out in forced-aerated windrows open to atmosphere without gas collection during a period of 6-8 weeks. The studied period presented in this work corresponds to year 2007. Although data obtained is only representative of the studied system, the methodology applied can be used in any other type of composting plants using different composting technologies.

\subsection{Step 1: Data collection on plant characteristics and operation}

The collection of data is systematically carried out using a specifically-designed questionnaire. Plant characteristics are classified into general, historical and socio-economical data and they include information such as plant capacity, soil occupation, characteristics of the final product 
obtained (compost) including amount and product destination, the quantities of waste treated and energy and water consumptions and other plant operation data. It is interesting to have reliable data on plant operation in order to relate the values of gaseous emissions obtained to these data and propose emission minimization options, if necessary. Plant operation data is then grouped and related to process main operations, i.e. reception, pre-treatment, waste decomposition phase, curing phase and post-treatment including type of process (composting technology), turning and/or aeration periodicity, watering, amount of rejected materials obtained from pre and posttreatment operations, type and amount of energy used (electric or fuel) and characteristics of the equipment and machinery used.

\subsection{Step 2: Determination of atmospheric emissions}

The pollutants studied in the present work were ammonia and total VOC. This group includes practically all types of hydrocarbons such as alkanes, alkenes, alcohols, ketones, aldehydes, organic acids, terpenes, etc., although the identification of single compounds present in VOC was out of the scope of this work. Ammonia was analyzed in situ using an Industrial Scientific multigas sensor iTX-T82 (Oakdale, PA, USA) with an ammonia detection range from 0 to 200 $\mathrm{mL} \mathrm{m}^{-3}$ and a temperature range from 20 to $50^{\circ} \mathrm{C}$. Total VOC were determined in the laboratory by gas chromatography (see Step 3) from gas samples obtained in the plant using 1 L Tedlar bags and a gas pump (SKC Universal de Luxe, Eighty Four, PA, USA).

The sampling methodology has been developed under the assumption that (i) gaseous emissions from the decomposition phase that takes place in closed composting reactors with air collection and treatment are limited to those released from the external surface of the biofilters and (ii) gaseous emissions from the curing phase are those released from curing windrows external surface. A systematic data collection on air velocity and gaseous compounds 
concentration in external surfaces of biolfilter and curing windrows was undertaken with minimal variations in the sampling methodology applied to these two types of emitting surfaces. The procedure followed is explained bellow:

- Measurement of the emitting surface: Height, length, width and perimeter of the curing windrow were measured.

- Definition of a matrix of sampling points covering the entire emitting surface: The number of sampling points has been determined on the basis of the dimensions of the curing windrow. Sampling points in the curing windrow were set by dividing it into five sampling profiles and considering three sampling points in each profile as shown in Figure 2. The distance within sampling profiles was $4 \mathrm{~m}$ (Figure 2a). One of the three sampling points considered in each profile was located at the top of the windrow and the other two at the windrow sides (Figures $2 \mathrm{~b}$ and $2 \mathrm{c}$ ).

- Determination of exhaust air velocity in each sampling point using a thermo-anemometer (VelociCalc Plus mod. 8386, TSI Airflow Instruments, UK). The anemometer was placed inside an open cubic plastic box $(0.5 \mathrm{~m} \times 0.5 \mathrm{~m} \times 0.5 \mathrm{~m})$ to minimize the effect of wind and air turbulences.

- $\quad$ Measurement of gaseous emissions: air velocity, ammonia and VOC concentrations were measured simultaneously in each sampling point. The three parameters were measured on the surface of the composting material without disturbing the gas flow pattern through the windrow. The product of compound concentration $\left(\mathrm{mg} \mathrm{m}^{-3}\right)$ and air velocity $\left(\mathrm{m} \mathrm{s}^{-1}\right)$ results in the mass flow of a given compound (ammonia or total VOC) released per windrow surface area unit $\left(\mathrm{mg} \mathrm{s}^{-1} \mathrm{~m}^{-}\right.$ ${ }^{2}$ ). Measures of gaseous emissions were repeated at different days during the composting process to determine the evolution of the emission of each compound. The periodicity of sampling was established as a function of plant operation and the development of the composting process. 
Differences among values obtained at each point of measurement were compared by means of a standard Student's t-test with a confidence of $95 \%$.

- Calculation of total ammonia and VOC emitted: data obtained from emission measurements during a single sampling day were represented in a three dimension graph with windrow length and perimeter in $\mathrm{x}$ and $\mathrm{y}$ axes respectively. The centre of the windrow was taken as the $(0,0)$ point in the graph. Ammonia or VOC mass flow value per square meter were placed in z-axis to obtain an emission surface for each pollutant. The three dimension emission surface was then projected in a two dimension graph (windrow perimeter at $\mathrm{x}$-axis and windrow length at $\mathrm{y}$-axis), where each pollutant emission per area unit is presented as iso-emission curves. Multiplying the pollutant mass flow per area unit by the corresponding area in the graph resulted in the compound mass flow and the sum of the different quantities obtained corresponds to the total mass flow of a pollutant $\left(\mathrm{g} \mathrm{s}^{-1}\right)$.

Finally, values of pollutant mass flow obtained for each sampling day were represented versus process time. The area below the curve obtained corresponds to the total mass of a given pollutant emitted throughout the composting process analyzed.

Emissions of carbon dioxide and VOC associated to energy consumption in form of diesel and electricity were also determined on the basis of the data provided by plant managers (ammonia was negligible in this case). Carbon dioxide emissions from the biological decomposition process are considered neutral as carbon emitted in this form has been previously fixed from the atmosphere by the organic matter under decomposition (Rabl et al., 2007).

\subsection{Step 3: Laboratory analysis}

Initial and final materials obtained during the composting process were sampled for analysis. Integrated samples were taken in order to obtain representative values (Barrena et al., 2006). 
Moisture, organic matter (OM) and nitrogen content (as $\mathrm{N}$-Kjeldahl) were determined following the methodology proposed by the US Department of Agriculture and the US Composting Council (2002). Biological activity was determined using the Respiration Index (RI), which measures the rate of oxygen consumption and it is usually conducted to determine compost stability (Gea et al., 2004). RI was determined as described in Barrena et al. (2005) and expressed as $\mathrm{mg} \mathrm{O}_{2}$ g organic matter ${ }^{-1} \mathrm{~h}^{-1}$.

Total VOC content from gaseous samples was determined as total carbon content (C-VOC) by direct injection of sample in a gas chromatograph (Agilent Technologies 6890N) using a flame ionization detector (FID) and a dimethyl polysiloxane $2 \mathrm{~m}$ x $0.53 \mathrm{~mm}$ column (Tracsil TRB-1, Teknokroma, Spain). This column permits the determination of the total C-VOC in a unique peak. The volume injected was $250 \mu \mathrm{L}$ and the analysis time was 1 min. The gas chromatography operating conditions were as follows: oven temperature isothermal at $200^{\circ} \mathrm{C}$, injector temperature $250^{\circ} \mathrm{C}$, FID temperature $250^{\circ} \mathrm{C}$; carrier gas helium at 1.5 psi pressure. Data were acquired and quantified by the Empower ${ }^{\circledR} 2$ software (Waters Associates Inc., Milford, USA) (Colón et al., 2009). n-hexane (99.9 \% purity) was used to quantify the VOC concentration in $\mathrm{mg} \mathrm{C} \mathrm{m}^{-3}$ (Spingo et al., 2003). The calibration curve was obtained by injecting different amounts of liquid n-hexane in a sealed Tedlar bag of known volume and analyzing a sample of the resulting gas (Torkian et al., 2003). A triplicate repetition was performed for each VOC concentration and the observed error of the method was below $10 \%$.

\subsection{Step 4: Calculation of emission factors}

Gaseous emissions generated in the treatment process are related to one Mg of OFMSW treated in the plant. This functional unit will permit future comparisons with other composting plants of different capacity. 
In addition to gaseous emissions, data on water and energy consumption collected in Step 1 were also related to the same functional unit as were the emissions associated to energy consumption. These emissions were calculated following the BUWAL 250 (Bundesamt für Umwelt, Wald und Landschaft, Swiss Agency for the Environment, Forests and Landscape) inventory implemented in Simapro 7.0 (PRé Consultants, Amersfoort, The Netherlands). Electrical power generation was considered according to sources contribution profile for Spain as described in the BUWAL database. This can be changed according to the location of each plant studied.

Another functional unit was also used in this study in order to relate emissions, water and energy to the real performance and extent of the biological treatment process. This new functional unit was the reduction in the biological activity of the material measured with the Respiration Index (RI) as reported in previous studies (Gea et al., 2004; Ponsá et al., 2008; Barrena et al., 2009).

\section{Results and discussion}

\subsection{Emissions case study}

The composting plant studied treated $6082 \mathrm{Mg}$ of OFMSW per year using pruning waste (1285

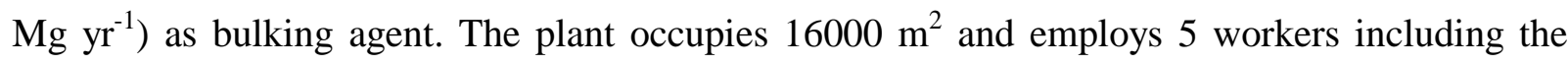
plant manager. Waste reception and waste pre-treatment and post-treatment areas (Figure 1) were located in a closed building with air collection and renewal. Air treatment was performed by means of a wet scrubber followed by a biofilter. Exhaust air from the composting reactors is also sent to the gas treatment units. Electric energy was used during in-vessel composting and windrow curing to provide the desired aeration whereas fuel was necessary for the machinery 
used for pre and post-treatment operations as well as for material transportation to the different areas of the plant. It is important to highlight that the first three days forced aeration in curing piles was constant (24 hours/day); after this initial period intermittent aeration (15 minutes on/15 minutes off) was used throughout the rest of the curing stage. Water necessary for moisture adjustment during the composting process, biofilter watering and in the wet scrubber came from a municipal wastewater treatment plant (WWTP) sited next to the composting plant. Water from the scrubber and leachate from composting reactors are re-sent to the WWTP for treatment. Rejected materials (impurities such as plastics, glass and metals in OFMSW separated from organic matter during pre-treatment operations and from final compost during material posttreatment) are daily collected from the plant and transported to a sanitary landfill.

Table 1 presents data on VOC concentration and air flow at the biofilter external surface. Two samples were taken each day during the studied period. As the values of gas velocity and contaminant concentration at the different sampling points on the biofilter surface were not statistically different $(\mathrm{p}>0.05)$, the existence of preferential pathways for the gas passing through the biofilter media was not considered in this case and VOC and ammonia concentration were determined in one of the sampling points established. In Table 1 a clear difference can be observed from day 21 until the end of the studied period due to operational changes and tests carried out in the biofilter and the previous scrubber, thus the quantity of VOC emitted from the biofilter was calculated taking into account only data collected from day 0 to 21 . Although this is a limitation of this study, the calculations necessary to obtain VOC overall emissions under any possible operational condition of the biofilter using the proposed methodology are relatively simple. Additionally, this fact demonstrates the suitability of the proposed methodology to detect changes occurring in gaseous emission sources. Assuming that during these first 21 days the biofilter was under optimal conditions, the calculated total VOC emission from the biofilter was 
of $0.006 \mathrm{~kg}_{\mathrm{VOC}} \mathrm{Mg} \mathrm{OFMSW}^{-1}$. Ammonia was not detected in the biofilter emission during the entire measurement period.

Figure 3 shows two examples of the emission surfaces obtained for ammonia in curing windrows. Figures $3 \mathrm{a}$ and $3 \mathrm{~b}$ correspond to the ammonia emission in days 2 and 14 of the curing period respectively. As can be seen in these two graphs maximum emissions are found on the top of the pile, which confirms other studies on composting emissions (Veeken et al., 2002). The prevalence of emissions location at the top of the windrow increases as process proceeds, when global emissions significantly decrease. Figures $3 \mathrm{c}$ and $3 \mathrm{~d}$ correspond to the two-dimension representation of Figures $3 \mathrm{a}$ and $3 \mathrm{~b}$ respectively from which the final value for ammonia mass flow in a sampling day was obtained.

Figure 4 presents the profile obtained when ammonia mass flow values determined for each day of sampling are represented versus process time. A total amount of $416 \mathrm{~kg}$ was calculated as total ammonia emission integrating the curve in Figure 4. If the initial amount of waste treated in the monitored windrow is known (106.5 Mg of OFMSW) the ammonia emission factor for the curing phase can be calculated resulting in $3.9 \mathrm{~kg} \mathrm{NH}_{3} \mathrm{Mg} \mathrm{OFMSW}^{-1}$.

Total VOC emission profile during the curing phase was obtained following the same procedure explained for ammonia and is it presented in Figure 5. No explanations were found about the relatively high values of VOC emissions observed in days 25-30, since these days did not coincide with any particular situation of the plant operation. The total quantity of VOC emitted was of $21.2 \mathrm{~kg}$. If this amount is again related to the quantity of OFMSW treated an emission factor of $0.20 \mathrm{~kg}$ VOC Mg OFMSW ${ }^{-1}$ is obtained for the curing phase.

Overall emission factors for the entire composting process were determined by adding values obtained during the decomposition and the curing phases. Total emission factors were $0.21 \mathrm{~kg}$ VOC $\mathrm{Mg} \mathrm{OFMSW}^{-1}$ and $3.9 \mathrm{~kg} \mathrm{NH}_{3} \mathrm{Mg} \mathrm{OFMSW}^{-1}$. It is difficult to find literature on ammonia 
or VOC emissions from full-scale composting processes as an exhaustive emission monitoring campaign is required to obtain representative and reliable values. Additionally, when values are compared with other studies it should be kept in mind that they are strongly related to the waste characteristics and process conditions. For instance, Clemens and Cuhls (2003) reported variable ammonia emissions (from 0.018 to $1.15 \mathrm{~kg} \mathrm{NH}_{3} \mathrm{Mg}$ waste $^{-1}$ ) when analyzing the composting process of OFMSW in different mechanical-biological treatment plants in Germany. Other values of ammonia emissions have been reported in pilot plant scale experiments. From the data provided by Beck-Friis et al. (2001) in their study on the influence of temperature on the emissions of ammonia during OFMSW composting in $200 \mathrm{~L}$ aerated reactors, a value of $2.12 \mathrm{~kg}$ $\mathrm{NH}_{3} \mathrm{Mg}$ waste ${ }^{-1}$ was obtained. These emissions correspond to a $24-33 \%$ of the nitrogen content in the starting composting material. In similar conditions (125 L aerated reactors), Elkind and Kirchmann (2000) reported an ammonia emission of $9.6 \mathrm{~kg} \mathrm{NH}_{3} \mathrm{Mg}_{\text {waste }}{ }^{-1}$ (70\% of the initial nitrogen). In all cases, the final value of ammonia emissions depended on the composting process duration and conditions and on the $\mathrm{C} / \mathrm{N}$ ratio of the initial waste. Ammonia emissions obtained in the present study correspond to a percentage of $46 \%$ of the nitrogen present in the composting material at the beginning of the curing phase.

There are fewer studies published in the case of VOC emission, especially at full scale. Under laboratory conditions, Staley et al. (2006) found a total VOC emission of $0.282 \mathrm{~kg} \mathrm{Mg}$ dry matter ${ }^{1}$ when composting a mixture of food waste, garden waste and non-recyclable paper in $8 \mathrm{~L}$ composting reactors. Smet et al. (1999) reported a cumulative VOC emission of $0.590 \mathrm{~kg}$ VOC $\mathrm{Mg}$ of waste $^{-1}$ during a pilot scale $(224 \mathrm{~L})$ composting experiment treating a similar waste. This value is equivalent to $1.51 \mathrm{~kg}$ VOC $\mathrm{Mg}$ of dry matter ${ }^{-1}$. The value of VOC emission during OFMSW composting obtained in the monitored plant of the present study $(0.21 \mathrm{~kg}$ VOC $\mathrm{Mg}$ of $\mathrm{OFMSW}^{-1}$ ) corresponds to a value of $0.82 \mathrm{~kg}$ VOC Mg of dry matter $^{-1}$. VOC emission has been 
reported to be strongly related to the process conditions (especially temperature and aeration rate), the composition of the waste and the ratio of bulking agent used (Pagans et al., 2006b).

In addition to the emissions from the composting process detailed above, Table 2 presents carbon dioxide and total VOC emissions derived from the production and use of the energy consumed in the plant (electricity and diesel). Contribution of VOC emissions associated to diesel consumption to the total emissions of these compounds should be highlighted. Table 2 also includes all the data on input and output flows associated to the composting plant studied (materials, energy and water) determined using the specifically-designed questionnaire explained in Step 1 of the experimental methodology. Water consumption (from the nearby WWTP) was $0.33 \mathrm{~m}^{3} \mathrm{Mg} \mathrm{OFMSW}^{-1}$, which was mainly used in the wet scrubber. Consumption of energy per $\mathrm{Mg}$ of OFMSW in the studied plant was of $3.4210^{5} \mathrm{~kJ}$ of electricity and $3.6 \mathrm{~L}$ of diesel. If diesel consumption is converted into $\mathrm{kJ}$ according to the factor proposed by the Queensland Government Environmental Protection Agency (2008) (1 L diesel is equivalent to $3.8410^{4} \mathrm{~kJ}$ ), the total amount of energy consumed is $4.8010^{5} \mathrm{~kJ} \mathrm{Mg} \mathrm{OFMSW}^{-1}$. Percentages of contribution of electricity and diesel to total energy use are of 71.3 and $28.7 \%$ respectively. These percentages are in accordance with those calculated by Blengini (2008) who determined electricity $\left(2.1910^{5} \mathrm{~kJ}\right)$ and diesel $(2.06 \mathrm{~L})$ needs in the composting of $1 \mathrm{Mg}$ of OFMSW. These values represent a contribution to the total energy consumption of $73 \%$ for electricity and $26.5 \%$ for diesel. Diggelman and Ham (2003) reported an energy consumption of $1.510^{6} \mathrm{~kJ} \mathrm{Mg}$ food waste $^{-1}$ in a composting plant including in-vessel decomposition followed by windrow curing while Fricke et al. (2005) determined the electricity needs for a forced-aeration composting process resulting in $1.0810^{5}-2.1610^{5} \mathrm{~kJ} \mathrm{Mg}$ of waste ${ }^{-1}$. The electricity used in the studied plant is mainly inverted in aeration of the material while diesel consumption is related to material handling and pre and post treatment operations. 


\subsection{Environmental impact and functional unit}

Data on Table 2 will permit the characterization and comparison of the different technologies used in OFMSW composting from an environmental point of view by considering the amount of resources consumed (energy and water), waste diverted to landfill and final compost produced per ton of OFMSW treated. Emission factors for the different compounds (ammonia, total VOC and carbon dioxide) are also of high interest when comparing the composting technology used with other waste treatment possibilities in terms of atmospheric pollution and also global warming potential. All these ratios can be considered as environmental performance indicators of a waste treatment plant. They are also crucial to perform an accurate Life Cycle Assessment.

However, it is also interesting to relate the emissions determined and other environmental performance indicators to the real efficiency of the composting process developed in terms of material stabilization and biodegradation. The need of a parameter that permits to relate the environmental indicators of a composting process to the biodegradation level achieved for the organic matter (by means of $\mathrm{O}_{2}$ consumed or $\mathrm{CO}_{2}$ produced) has also been stated by Amlinger et al. (2008). These authors proposed the ratio between methane produced and total $\mathrm{CO}_{2}$ emissions as an indicator of the efficiency of the aerobic decomposition process and also the ratio between $\mathrm{kg} \mathrm{CO}$ equivalent (obtained by computing $\mathrm{N}_{2} \mathrm{O}$ and methane emissions and total $\mathrm{CO}_{2}$ produced) to relate greenhouse gases emissions to the efficiency of aerobic decomposition and organic matter transformation. However, this procedure implies to measure all the biogenic $\mathrm{CO}_{2}$ produced in the composting process to have an efficiency unit to refer all the environmental impacts. Another possible approach is to use a global aerobic activity indicator such as respiration index. This seems a more straightforward indicator to evaluate the extent and efficiency of a biological process because it only needs to collect an initial sample (OFMSW) and a final sample (compost) 
to calculate the difference in the oxygen uptake rate, which is in fact the stabilization achieved in the composting plant. This is also carried out in wastewater treatment plants, but in that case the Biochemical Oxygen Demand is used as measure of the initial and remaining oxygen uptake rate.

In the case of the studied plant, RI initial and final values of the treated material were 5.8 and $1.08 \mathrm{mg} \mathrm{O}_{2} \mathrm{~g} \mathrm{OM}^{-1} \mathrm{~h}^{-1}$ respectively, which corresponded to $81 \%$ of reduction in the biological activity of the material. If the values of the different emission factors in Table 2 are divided by the RI reduction achieved in the process $\left(4.72 \mathrm{mg} \mathrm{O}_{2} \mathrm{~g} \mathrm{OM}^{-1} \mathrm{~h}^{-1}\right)$ and also by the organic matter content of the OFMSW (2.73 $\left.10^{5} \mathrm{~g} \mathrm{OM} \mathrm{Mg} \mathrm{OFMSW}^{-1}\right)$, the values obtained can be expressed as amounts of energy, water or contaminant (needed or emitted) per unit of oxygen uptake reduced $\left(\mathrm{kg} \mathrm{O}_{2} \mathrm{~h}^{-1}\right)$. Values referred to this new functional unit are summarized in Table 3. However, this novel approach has not been previously described in literature, and therefore no comparison can be presented. The importance of referring the environmental impacts to both functional units (mass of treated waste and biodegradation efficiency) relies on the fact that the environmental impact per mass of waste can be directly used in LCA studies to compare different composting technologies or waste treatment alternatives, whereas in the case of using the biodegradation efficiency as functional unit the values obtained can help in the detection of problems in the plant operation and for the proposal of measures intended to improve the process by reducing the most significant environmental impacts.

\section{Conclusions}

A methodology has been developed and successfully applied to determine total VOC and ammonia emissions in a composting plant. Ammonia was detected in gaseous emissions from the curing aerated windrows but it was not detected in the biofilter exhaust gases. VOC were present in both gaseous emissions sources. Emission factors of $3.9 \mathrm{~kg} \mathrm{NH}_{3} \mathrm{Mg} \mathrm{OFMSW}^{-1}$ and $0.21 \mathrm{~kg}$ 
VOC Mg OFMSW ${ }^{-1}$ for the composting process were determined when the treatment of one $\mathrm{Mg}$ of OFMSW was considered as the functional unit. Although in this study the methodology developed has been applied to a specific configuration of a composting plant, it can be applied to different technologies and wastes.

A new functional unit was proposed to reflect the efficiency of the composting process in terms of biological activity and biodegradation level achieved in the material treated. The respiration index (RI), a global aerobic activity indicator, was selected for this purpose. Thus, gaseous emissions have been also related to RI reduction achieved in the process (from 5.8 to $1.08 \mathrm{mg} \mathrm{O}_{2}$ $\mathrm{g} \mathrm{OM}^{-1} \mathrm{~h}^{-1}$, which corresponded to $81 \%$ of reduction in the biological activity). The functional unit proposed can help in presenting the emissions of a composting plant on a more realistic basis since, for instance, low emissions can be incorrectly interpreted as low impacts if they are due to an inefficient biological process. To refer the gaseous emissions, a value of RI of $0.5-1 \mathrm{mg} \mathrm{O}_{2} \mathrm{~g}$ $\mathrm{OM}^{-1} \mathrm{~h}^{-1}$ has been proposed as an indicator of compost stability in some European regulations (Barrena et al., 2005), although there is still no consensus on the way to determine biological stability .

Emissions associated to energy consumption and water needs and rejected waste production were also determined for the studied plant and related to both functional units used.

The values obtained and the methodology proposed can be useful to compare different composting technologies and other biological treatments applied to organic wastes in terms of environmental performance indicators. When comparing different facilities it should be taken into account that they must have similar objectives regarding to the quality and stability required for the final product (compost). Data obtained from this type of studies may contribute to enhance the Life Cycle Assessment on waste treatment field. 


\section{Acknowledgment}

This study was financially supported by the Agència de Residus de Catalunya and the Spanish Ministerio de Educación y Ciencia (Project CTM2006-00315/TECNO). Erasmo Cadena and Joan Colón thank to Universidad Autónoma de Tamaulipas and Universitat Autònoma de Barcelona respectively for the award of a pre-doctoral fellowship. 


\section{References}

Amlinger, F., Peyr, S., Cuhls, C., 2008. Green house gas emissions from composting and mechanical biological treatment. Waste Management and Research 26, 47-60.

Banar, M., Cokaygil, Z., Ozkan, A., 2009. Life cycle assessment of solid waste management options for Eskisehir, Turkey. Waste Management 29, 54-62.

Barrena, R., Vázquez, F., Gordillo, M.A., Gea, T., Sánchez, A., 2005. Respirometric assays at fixed and process temperatures to monitor composting process. Bioresource Technology 96, 1153-1159.

Barrena, R., Pagans, E., Faltys, G., Sánchez, A., 2006. Effect of inoculation dosing on the composting of source-selected organic fraction of municipal solid wastes. Journal of Chemical Technology and Biotechnology 81, 420-425.

Barrena, R., d’Imporzano, G., Ponsá, S., Gea, T., Artola, A., Vázquez, F., Sánchez, A., Adani, F., 2009. In search of a reliable technique for the determination of the biological stability of the organic matter in the mechanical-biological treated waste. Journal of Hazardous Materials 162, 1065-1072.

Beck-Friis, B., Smars, S., Jönsson, H., Kirchmann, H., 2001. Gaseous emissions of carbon dioxide, ammonia and nitrous oxide from organic household waste in a compost reactor under different temperature regimes. Journal of Agriculture Engineering Research 78, 423-430.

Blengini, G.A., 2008. Using LCA to evaluate impacts and resources conservation potential of composting: A case study of the Asti District in Italy. Resources Conservation and Recycling 52, 1373-1381. 
Clemens, J., Cuhls, C., 2003. Greenhouse gas emissions from mechanical and biological waste treatment of municipal waste. Environmental Technology 24, 745-754.

Colón, J., Martínez-Blanco, J., Gabarrell, X., Rieradevall, J., Font, X., Artola, A., Sánchez, A., 2009. Performance of an industrial biofilter from a composting plant in the removal of ammonia and VOCs after material replacement. Journal of Chemical Technology and Biotechnology, available on-line: DOI 10.1002/jctb.2139.

Cronje, A.L., Barker, A.J., Guy, S., Turner, C., Williams, A.G., 2002. Ammonia emissions and pathogen inactivation during composting. In: Michel, F.C., Rynk, R.F., Hoitink, H.A.J. (Eds.), Proceedings of the 2002 International Symposium Composting and Compost Utilization. JG Press, Emmaus, Pennsylvania, 845-856.

Defoer, N., De Bo, I., Van Langenhove, H., Dewulf, J., Van Elst, T., 2002. Gas chromatographymass spectrometry as a tool for estimating odour concentrations of biofiltre effluents at aerobic composting and rendering plants. Journal of Chromatography A 970, 259-273.

Diggelman, C., Ham, R.K., 2003. Household food waste to wastewater or to solid waste? That is the question. Waste Management and Research 21, 501-514.

Domingo, J.L., Nadal, M., 2009. Domestic waste composting facilities: A review of human health risks. Environment International 35, 382-389.

Eitzer, B.D., 1995. Emissions of Volatile Organic Chemicals from municipal solid waste composting facilities. Environmental Science and Technology 29, 896-902.

Eklind, Y., Kirchmann, H., 2000. Composting and storage of organic household waste with different litter amendments. II: nitrogen turnover and losses. Bioresource Technology 74, 125-133. 
Emery, A., Davies, A., Griffiths, A., Williams, K., 2007. Environmental and economic modelling: A case study of municipal solid waste management scenarios in Wales. Resources Conservation and Recycling 49, 244-263.

Eriksson, O., Carlsson Reich, M., Frostell, B., Björklund, A., Assefa, G., Sundqvist, J.O., Granath, J., Baky, A., Thyselius, L., 2005. Municipal solid waste management from a systems perspective. Journal of Cleaner Production 13, 241-252.

European Commission (1999). Council Directive 1999/31/EC of 26 April 1999 on landfill of waste. Official Journal of the European Communities, L 182/1-19, 16/7/1999.

European Commission (2000). Commission Decision of 17 July 2000. The European Pollutant Emission Register (EPER) Decision is based on Article 15(3) of Council Directive 96/61/EC concerning integrated pollution prevention and control.

Fricke, K., Santen, H., Wallmann, R., 2005. Comparison of selected aerobic and anaerobic procedures for MSW treatment. Waste Management 25, 799-810.

Gea, T., Barrena, R., Artola, A., Sánchez, A., 2004. Monitoring the biological activity of the composting process: oxygen uptake rate (OUR), respirometric index (RI) and respirometric quotient (RQ). Biotechnology and Bioengineering 88, 520-527.

Grunditz, C., Dalhammar, G., 2001. Development of nitrification inhibition assays using pure cultures of Nitrosomonas and Nitrobacter. Water Research 35, 433-440.

Güereca, L.P., Gassó, S., Baldasano, J.M., Jiménez-Guerrero, P., 2006. Life cycle assessment of two biowaste Management Systems for Barcelona, Spain. Resources Conservation and Recycling 49, 32-48.

Haug, R.T., 1993. The practical handbook of compost engineering. Lewis Publishers, Boca Raton, Florida, USA. 
Homas, W.J., Fischer, K., 1992. A composting plant as an odour source, compost as an odour killer. Acta Horticulturae 302, 37-44.

Komilis, D.P., Ham, R.K., Park, J.K., 2004. Emission of volatile organic compounds during composting of municipal solid wastes. Water Research 38, 1707-1714.

Lee, S.H., Chio, K.I., Osako, M., Dong, J.I., 2007. Evaluation of environmental burdens caused by changes of food waste management systems in Seoul, Korea. Science of the Total Environment 387, 42-53.

Mao, I.F., Tsai, C.J., Shen, S.H., Lin, T.F., Chen, W.K., Chen, M.L., 2006. Critical components of odors in evaluating the performance of food waste composting plants. Science of the Total Environment 370, 323-329.

Ministerio de Medio Ambiente y Medio Rural y Marino, 2009. Gestión de residuos sólidos urbanos año 2005 (in Spanish, accessed May 2009). http://www.mma.es/portal/secciones/calidad_contaminacion/residuos/estadisticas_residuo s/residuos_urbanos.htm

Mor, S., Ravindra, K., de Visscher, A., Dahiya, R.P., Chandra, A., 2006. Municipal solid waste characterization and its assessment for potential methane generation: A case study. Science of the Total Environment 371, 1-10.

Pagans, E., Barrena, R., Font, X., Sánchez, A., 2006a. Ammonia emissions from the composting of different organic wastes. Dependency on process temperature. Chemosphere 62, 15341542.

Pagans, E., Font, X., Sánchez, A., 2006b. Emission of volatile organic compounds from composting of different solid wastes. Abatement by biofiltration. Journal of Hazardous Materials 131, 179-186. 
Ponsá, S., Gea, T., Alerm, L., Cerezo, J., Sánchez, A., 2008. Comparison of aerobic and anaerobic stability indices through a MSW biological treatment process. Waste Management 28, 2735-2742.

Queensland Government Environmental Protection Agency, 2008. EcoBiz Program, Conversions and Units, Queensland, Australia. URL: www.epa.qld.gov.au/ecobiz (accessed February 2009).

Rabl, A., Benoist, A., Dron, D., Peuportier, B., Spadaro, J.V., Zoughaib, A., 2007. How to Account for $\mathrm{CO}_{2}$ Emissions from Biomass in an LCA. International Journal of Life Cycle Assessment 12, 281

Smet, E., Van Langenhove, H., De Bo, I., 1999. The emission of volatile compounds during the aerobic and the combined anaerobic/aerobic composting of biowaste. Atmospheric Environment 33, 1295-1303.

Spingo, G., Pagella, C., Daria Fumi, M., Molteni, R., De Faveri, D.M., 2003. VOCs removal from waste gases: gas-phase bioreactor for abatement of hexane by Aspergillus niger. Chemical Engineering Science 58, 739-746.

Staley, B.F., Xu, F., Cowie, S.J., Barlaz, M.A., Hater, G.R., 2006. Release of trace organic compounds during the decomposition of municipal solid waste components. Environmental Science and Technology 40, 5984-5991.

Szanto, G.L., Hamelers, H.V.M., Rulkens, W.H., Veeken, A.H.M., 2007. $\mathrm{NH}_{3}, \mathrm{~N}_{2} \mathrm{O}$ and $\mathrm{CH}_{4}$ emissions during passively aerated composting of straw-rich pig manure. Bioresource Technology 98, 2659-2670.

The US Department of Agriculture and The US Composting Council, 2002. Test Methods for the Examination of Composting and Compost (TMECC). Edaphos International, Houston, USA. 
Tolvanen, O., Nykanen, J., Nivukoski, U., Himanen, M., Veijanen, A., Hanninen, K., 2005. Occupational hygiene in a Finnish drum composting plant. Waste Management 25, 427433.

Torkian, A., Dehghanzadeh, R., Hakimjavadi, M., 2003. Biodegradation of aromatic hydrocarbons in a compost biofilter. Journal of Chemical Technology and Biotechnology $78,795-801$.

Van Durme, G.P., McNamara, B.F., McGinley, C.M., 1992. Bench-scale removal of odor and volatile organic compounds at a composting facility. Water Environment and Research 64, 19-27.

Veeken, A., de Wilde, V., Hamelers, B., 2002. Passively aerated composting of straw-rich pig manure: Effect of compost bed porosity. Compost Science and Utilization 10, 114-128. 


\section{Tables}

Table 1. VOC emissions from the biofilter of the studied OFMSW composting plant. Results of VOC concentration and VOC emission rate are expressed as the average value and the standard deviation of two independent measurements carried out each day.

\begin{tabular}{cccc}
\hline $\begin{array}{c}\text { Day of } \\
\text { measurement }\end{array}$ & Air velocity $\left(\mathrm{m} \mathrm{s}^{-1}\right)$ & $\begin{array}{c}\text { VOC concentration } \\
\left(\mathrm{mg} \mathrm{C}-\mathrm{VOC}{ }^{-3}\right)\end{array}$ & $\begin{array}{c}\text { VOC emission rate } \\
\left(\mathrm{kg} \mathrm{C}-\mathrm{VOC} \mathrm{d}^{-1}\right)\end{array}$ \\
\hline 0 & 0.08 & $0.071 \pm 0.039$ & $0.709 \pm 0.391$ \\
3 & 0.09 & $0.037 \pm 0.010$ & $0.409 \pm 0.110$ \\
7 & 0.07 & $0.054 \pm 0.021$ & $0.471 \pm 0.182$ \\
14 & 0.06 & $0.057 \pm 0.001$ & $0.422 \pm 0.008$ \\
21 & 0.08 & $0.437 \pm 0.078$ & $4.348 \pm 0.776$ \\
35 & 0.08 & $0.223 \pm 0.056$ & $2.213 \pm 0.558$ \\
42 & 0.07 & $0.260 \pm 0.024$ & $2.263 \pm 0.208$ \\
49 & 0.08 & $0.513 \pm 0.082$ & $5.103 \pm 0.810$ \\
56 & 0.06 & $0.393 \pm 0.228$ & $2.932 \pm 1.702$ \\
63 & 0.06 & $0.749 \pm 0.406$ & $5.587 \pm 3.26$ \\
\hline
\end{tabular}


Table 2. Input and output flows in the studied composting plant. Functional unit: $1 \mathrm{Mg}$ OFMSW (data corresponding to year 2007).

\begin{tabular}{|c|c|c|c|}
\hline \multirow{7}{*}{$\stackrel{\mathscr{Z}}{\Xi}$} & $\begin{array}{l}\text { Raw } \\
\text { materials }\end{array}$ & $\begin{array}{l}\text { t OFMSW } \mathrm{y}^{-1} \\
\text { t bulking agent } \mathrm{y}^{-1}\end{array}$ & $\begin{array}{l}6082.3 \\
1285.3\end{array}$ \\
\hline & & kJ electricity $\mathrm{Mg}_{\mathrm{OFMSW}}{ }^{-1}$ & $3.4210^{5}$ \\
\hline & & $\mathrm{L}_{\text {gasoil }} \mathrm{Mg} \mathrm{OFMSW}^{-1}$ & 3.6 \\
\hline & & $\mathrm{m}^{3}$ water used in gas treatment $\mathrm{Mg} \mathrm{OFMSW}^{-1}$ & 0.19 \\
\hline & Resources & $\begin{array}{l}\mathrm{m}^{3} \text { water used in composting process } \mathrm{Mg} \\
\text { OFMSW }^{-1}\end{array}$ & 0.14 \\
\hline & & Total $\mathrm{m}^{3}$ water Mg OFMSW ${ }^{-1}$ & 0.33 \\
\hline & & $\mathrm{m}^{3}$ tap water $\mathrm{y}^{-1}$ & 96 \\
\hline \multirow{9}{*}{ 营 } & \multirow{4}{*}{$\begin{array}{l}\text { Atmospheric } \\
\text { emissions } \\
\text { (energy) }\end{array}$} & $\mathrm{kg} \mathrm{CO}_{2}$ electricity $\mathrm{Mg}_{\mathrm{OFMSW}}{ }^{-1}$ & 50.2 \\
\hline & & $\mathrm{kg} \mathrm{CO}_{2}$ diesel Mg OFMSW ${ }^{-1}$ & 10.3 \\
\hline & & kg VOC electricity Mg OFMSW ${ }^{-1}$ & 0.02 \\
\hline & & kg VOC diesel Mg OFMSW ${ }^{-1}$ & 0.64 \\
\hline & \multirow{2}{*}{$\begin{array}{l}\text { Atmospheric } \\
\text { emissions } \\
\text { (composting } \\
\text { process) }\end{array}$} & $\mathrm{kg} \mathrm{NH}_{3} \mathrm{Mg} \mathrm{OFMSW}^{-1}$ & 3.9 \\
\hline & & kg VOC Mg OFMSW ${ }^{-1}$ & 0.21 \\
\hline & \multirow{2}{*}{ Product } & Mg compost $\mathrm{y}^{-1}$ & 566.6 \\
\hline & & Mg compost $\mathrm{Mg}$ OFMSW $^{-1}$ & 0.09 \\
\hline & Refuse & 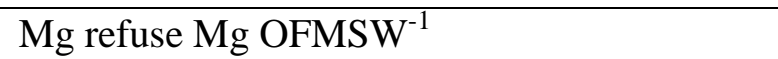 & 0.25 \\
\hline
\end{tabular}


Table 3. Emission factors, energy and water consumption related to total biodegradation of the material expressed as Respiration Index (RI).

\begin{tabular}{llc}
\hline & $\mathrm{kJ}\left(\mathrm{kg} \mathrm{O}_{2} \mathrm{~h}^{-1}\right)^{-1}$ & 260000 \\
\cline { 2 - 3 } Resources & $\mathrm{L}$ gasoil $\left(\mathrm{kg} \mathrm{O}_{2} \mathrm{~h}^{-1}\right)^{-1}$ & 2.78 \\
\cline { 2 - 3 } & $\mathrm{m}^{3}$ water $\left(\mathrm{kg} \mathrm{O}_{2} \mathrm{~h}^{-1}\right)^{-1}$ & 0.256 \\
\hline & $\mathrm{kg} \mathrm{CO}_{2}\left(\mathrm{~kg} \mathrm{O}_{2} \mathrm{~h}^{-1}\right)^{-1}$ & 46.95 \\
Atmospheric emissions & $\mathrm{kg} \mathrm{VOC}\left(\mathrm{kg} \mathrm{O}_{2} \mathrm{~h}^{-1}\right)^{-1}$ & 0.657 \\
& & 3.03 \\
& $\mathrm{~kg} \mathrm{NH}\left(\mathrm{kg} \mathrm{O}_{2} \mathrm{~h}^{-1}\right)^{-1}$ & \\
\hline
\end{tabular}




\section{Figure captions}

Figure 1. Schematic diagram of the studied composting plant: a) Plant input and output flows (dashed line indicates the limits of the system considered), b) Composting mass balance (100 $\mathrm{kg}$ of OFMSW input is selected as base for mass balance).

Figure 2. Example of distribution of gaseous emission sampling points in a composting windrow: a) sampling profiles on a side view of the windrow, b) sampling points in a profile in a frontal view, c) sampling points represented in a windrow upper view.

Figure 3. Ammonia emissions from the forced aerated curing windrow a) Ammonia profile at the second day of curing, b) Ammonia profile at the second week of curing c) Two dimension projection of the ammonia emission profile at the second day of curing d) Two dimension projection of the ammonia emission profile at the second week of curing.

Figure 4. Ammonia mass flow in the forced aerated curing windrow obtained on each sampling day.

Figure 5. Total VOC mass flow in the forced aerated curing windrow obtained on each sampling day. 
Figure 1.

a)

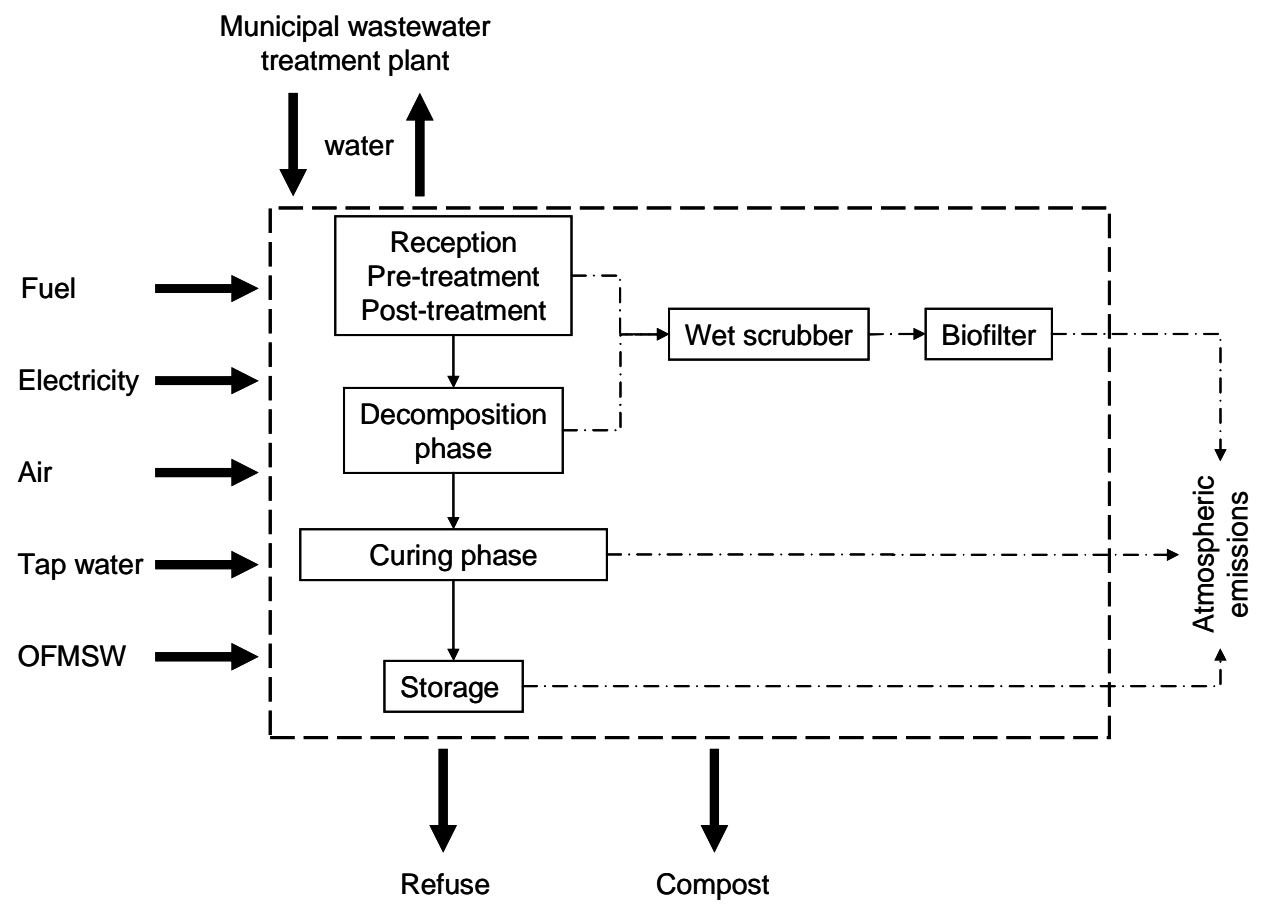

b)

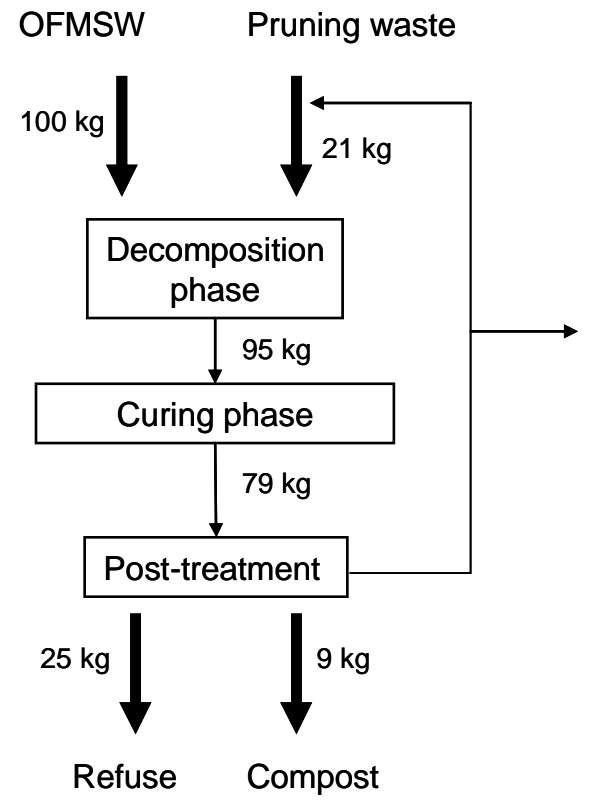


Figure 2.

a

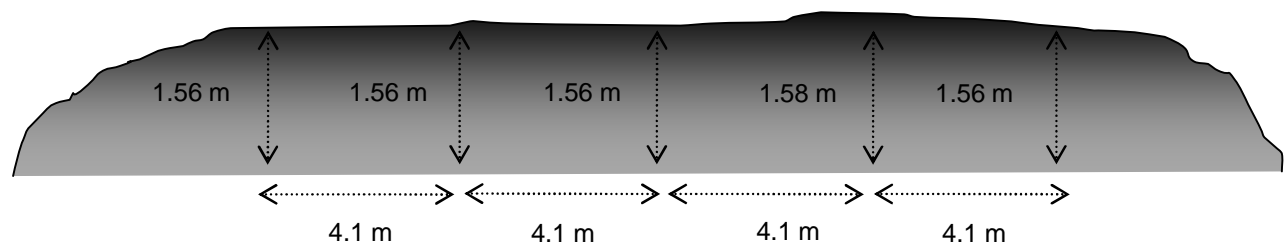

b

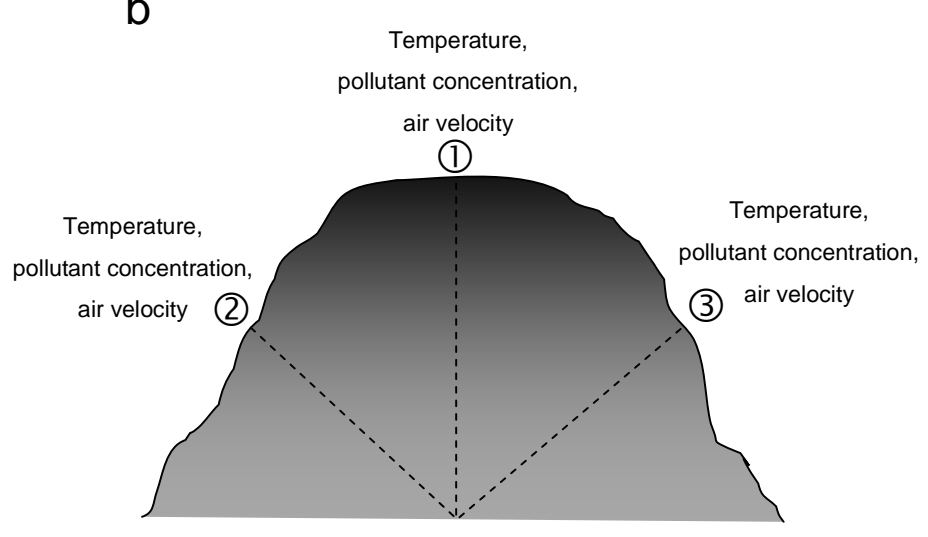

C

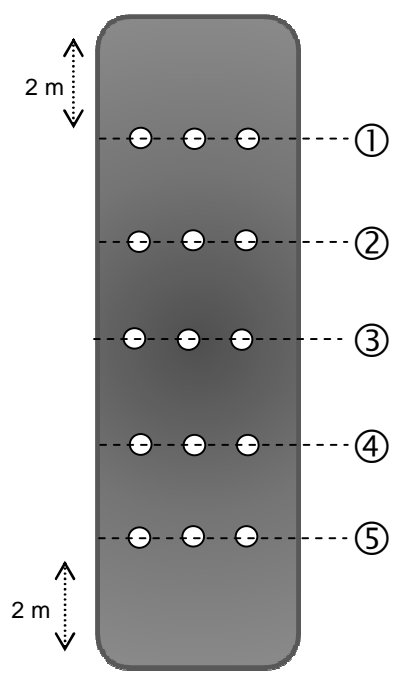


Figure 3.

a

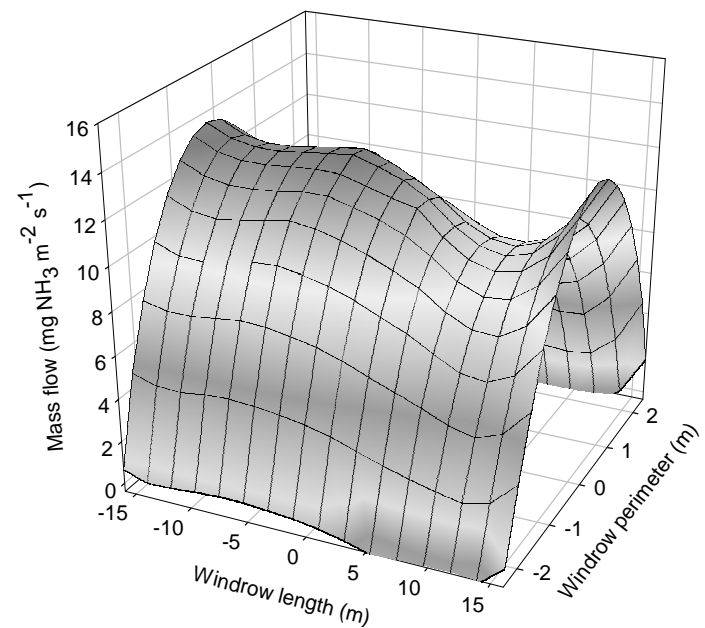

C

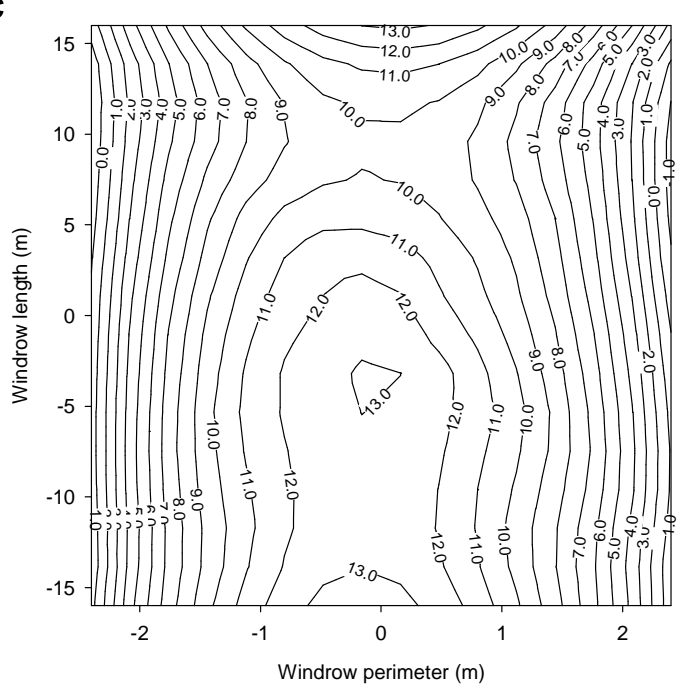

b

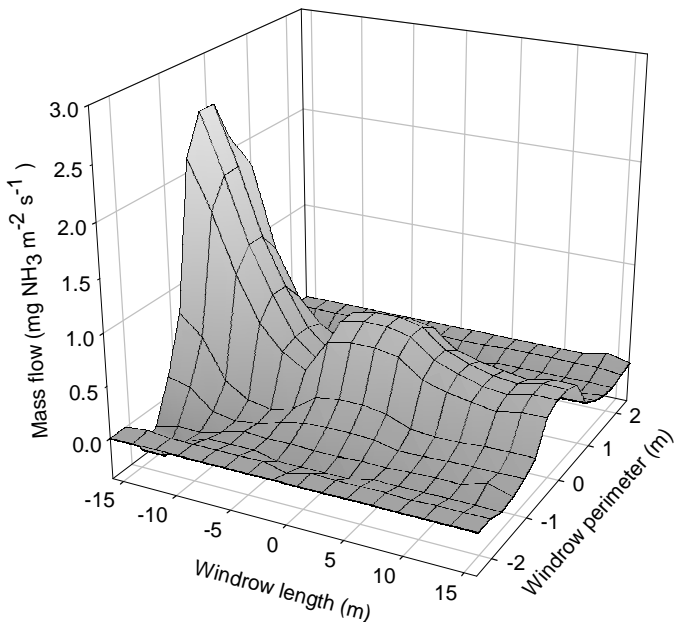

d

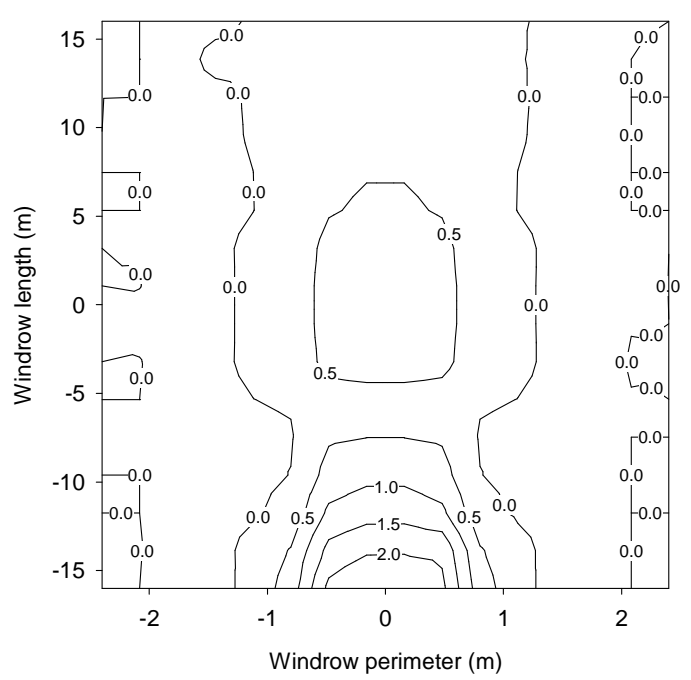


Figure 4.

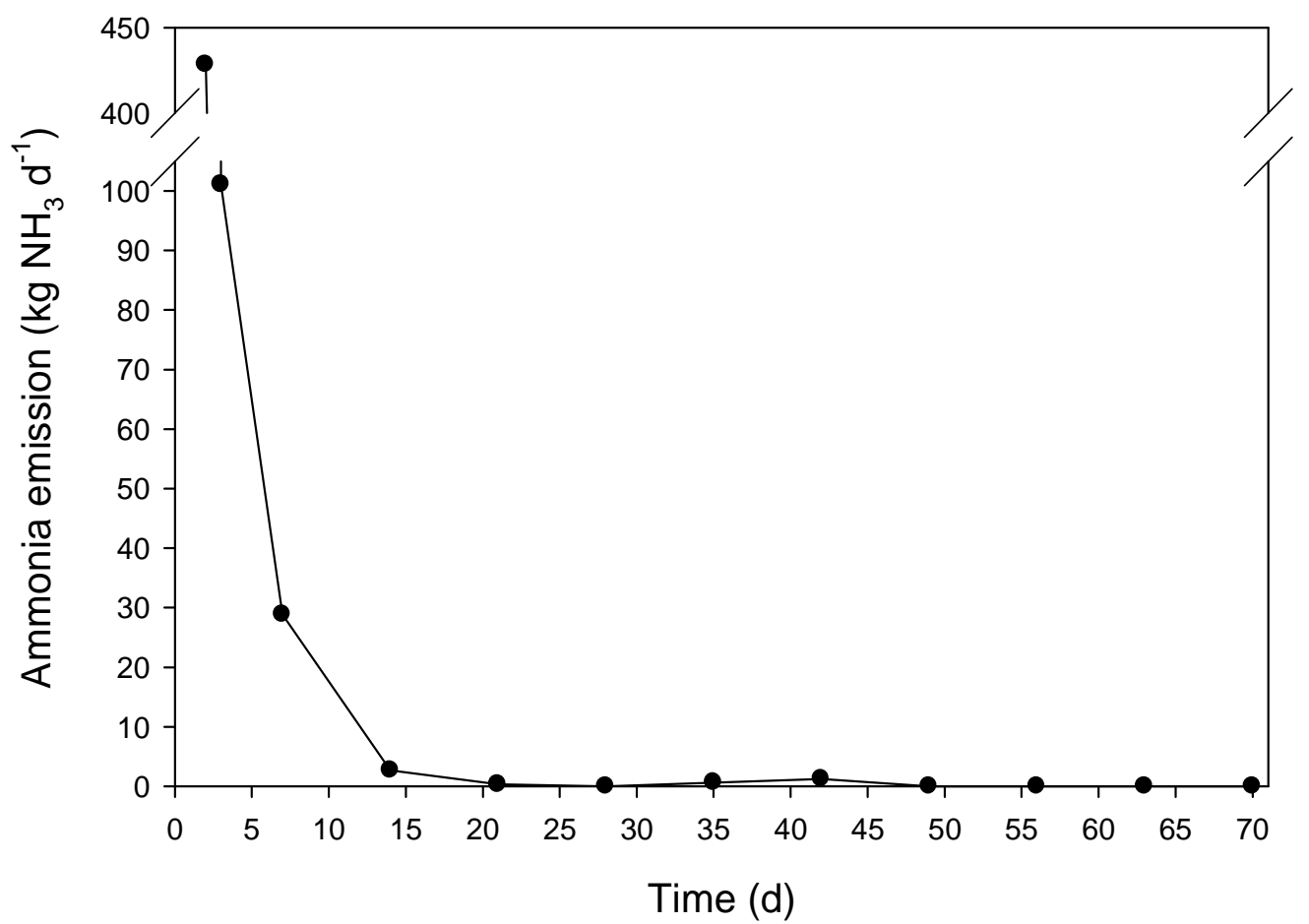


Figure 5.

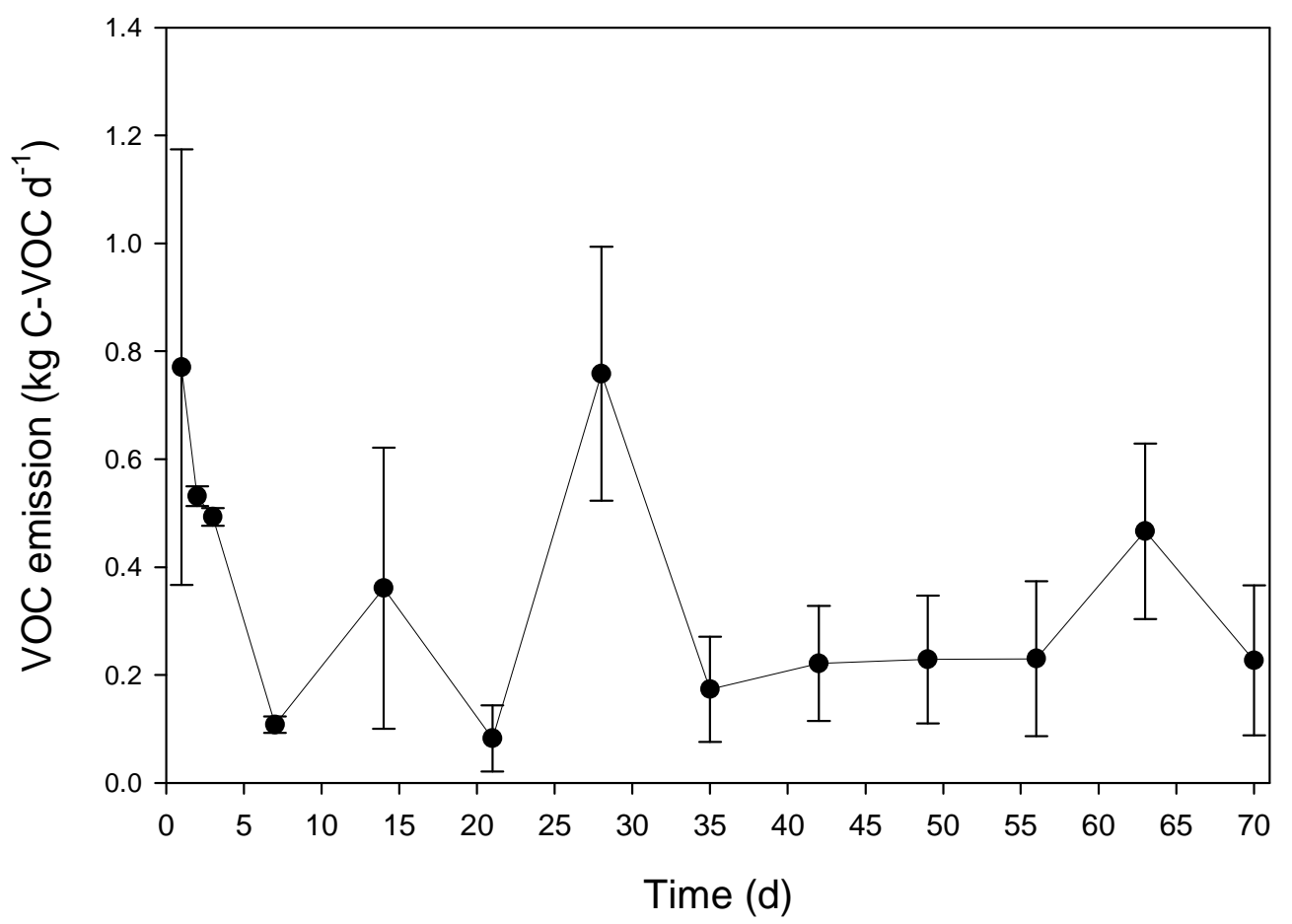

